\title{
Unregulated Emissions from Natural Gas Taxi Based on IVE Model
}

\author{
Hong Zhao *, Liang Mu, Yan Li, Junzheng Qiu, Chuanlong Sun and Xiaotong Liu \\ College of Mechanical and Electrical Engineering, Qingdao University, Qingdao 260071, China; \\ 2019025845@qdu.edu.cn (L.M.); 2019025843@qdu.edu.cn (Y.L.); 2019025836@qdu.edu.cn (J.Q.); \\ 2020020440@qdu.edu.cn (C.S.); 2020025567@qdu.edu.cn (X.L.) \\ * Correspondence: zhaohong@qdu.eu.cn
}

Citation: Zhao, H.; Mu, L.; Li, Y.; Qiu, J.; Sun, C.; Liu, X. Unregulated Emissions from Natural Gas Taxi Based on IVE Model. Atmosphere 2021, 12, 478. https://doi.org/10.3390/ atmos12040478

Academic Editors: Yuhan Huang and Georgios Karavalakis

Received: 11 March 2021

Accepted: 6 April 2021

Published: 9 April 2021

Publisher's Note: MDPI stays neutral with regard to jurisdictional claims in published maps and institutional affiliations.

Copyright: (c) 2021 by the authors. Licensee MDPI, Basel, Switzerland. This article is an open access article distributed under the terms and conditions of the Creative Commons Attribution (CC BY) license (https:// creativecommons.org/licenses/by/ $4.0 /)$.
Abstract: Emissions from motor vehicles have gained the attention of government agencies. To alleviate air pollution and reduce the petroleum demand from vehicles in China, the policy of "oil to gas" was vigorously carried out. Qingdao began to promote the use of natural gas vehicles (NGVs) in 2003. By the end of 2016, there were 9460 natural gas (NG) taxis in Qingdao, which accounted for $80 \%$ of the total taxis. An understanding of policy implementation for emission reductions is required. Experiments to obtain the taxi driving conditions and local parameters were investigated and an international vehicle emissions (IVE) localization model was established. Combined with vehicle mass analysis system (VMAS) experiments, the IVE localization model was amended and included the taxi pollutant emission factors. The result indicates that annual total carbon monoxide (CO) emissions from actual taxis are $6411.87 \mathrm{t}$, carbureted hydrogen $(\mathrm{HC})$ emissions are $124.85 \mathrm{t}$, nitrogen oxide (NOx) emissions are $1397.44 \mathrm{t}$ and particulate matter (PM) emissions are $8.9 \mathrm{t}$. When the taxis are running on pure natural gas, the annual emissions of CO, HC, NOx and PM are $4942.3 \mathrm{t}, 48.15 \mathrm{t}$, $1496.01 \mathrm{t}$ and $5.13 \mathrm{t}$, respectively. Unregulated emissions of annual total formaldehydes, benzene, acetaldehyde, 1,3-butadience emissions from an actual taxi are $65.99 \mathrm{t}, 4.68 \mathrm{t}, 1.04 \mathrm{t}$ and $8.83 \mathrm{t}$. When the taxi is running on pure natural gas, the above unregulated emissions are $12.11 \mathrm{t}, 1.27 \mathrm{t}, 1.5 \mathrm{t}$ and $0.02 \mathrm{t}$, respectively.

Keywords: unregulated emissions; natural gas taxi; emission factor correction; operating condition; IVE model

\section{Introduction}

Since China entered the 21st century, the national economy has developed rapidly and the pace of urban construction is increasing. With the gradual improvement of the urban road traffic network in recent years, the number of civilian cars in China has grown rapidly. The increase in the number of motor vehicles brings people convenient and fast travel, but it also causes an increasingly serious environmental pollution problem. Vehicle emissions draw more and more attention to the environment and society. The emissions from automobile exhausts are related to people's health [1-3]. The automobile power source is the key point of the continuous development of the automobile industry [4]. Good alternative fuels, such as biodiesel, alcohols and compressed natural gas (CNG), have solved some environmental problems, as well as some energy problems [5-7]. However, since the beginning of 2013, many places in China had hazy weather, which slowly spread to the surrounding areas from Beijing, Tianjin as well as Hebei. Urgent measures need to be taken to reduce vehicle emissions. The vehicle emission inventories of different cities and road grades have been researched [8-11].

Regarded as a promising alternative fuel, natural gas has comparatively large reserves, high combustion efficiency and low emissions. A few years ago, CNG vehicles were widely promoted in China to alleviate air pollution and reduce petroleum dependence. At present, many scholars have adopted various technological methods to reduce vehicle exhaust emissions and evaluated their effectiveness [12-15]. Due to this rapidly increasing alternative 
motor vehicle population, estimates of its emission levels are required. The emissions from compressed natural gas fueled taxis and buses were measured using a portable emission measurement system (PEMS) [16] under actual driving conditions [17-21]. Nesamani estimated the emissions from on-road vehicles in Chennai using the International Vehicle Emission (IVE) model [22] that examined various mitigation options to reduce vehicular emissions $[23,24]$. A simulation study of engine failure of LPG taxi and its impact on emission and vehicle performance by Organ Bruce [25] shows that the daily mileage of a taxi is longer than that of a private car, and it is concentrated on the sections of crowded roads in urban areas. Therefore, although the number of taxis is less than that of private cars, it still accounts for a large part of the exhaust emissions of urban motor vehicles.

However, these studies are entirely about regulated emissions and are limited to the emissions of volatile organic compounds (VOCs) [26-32]. Few studies have investigated the unregulated emissions of urban taxis, such as formaldehydes, benzene, etc. In this study, taxi driving conditions and local parameters were obtained through experimental equipment, such as chassis dynamometer and taxi driving conditions, and an IVE positioning model of the main roads in three districts of Qingdao was established. Combined with vehicle mass analysis system (VMAS) [33-36] experiments, the IVE localization model was amended and then Qingdao taxi pollutant emission factors were included, and the effects of different fuel on regulated and unregulated emission characteristics of urban taxis were investigated. The urban area of Qingdao has the same road conditions as most urban areas, so this study is universal to other cities. This paper also provides a basis for the promotion of Qingdao's "oil to gas" policy.

\section{Materials and Methods}

\subsection{Data Collection and Test Methods}

Three districts of Qingdao, Shinan, Laoshan and Licang, were selected. These were representative of the business district, a higher income area and a lower income area, respectively. Nine typical roads, including an expressway, main road and a neighborhood road in these three districts were tested. During experiments, distributions of Vehicle Specific Power (VSP) [37-40] and start status information were investigated. The typical daily traffic periods include morning peak hour, evening peak hour and off-peak hour. According to the actual situation of Qingdao, blocks which have more taxis were chosen as the test areas. Taxi operating history was measured using GPRS-V36. For other local parameters, such as taxi type, model-year, mileage, number of starts, fuel and emission, control levels were collected and analyzed by a questionnaire. The emissions of measured taxis were tested by vehicle mass analysis system (VMAS).

\subsection{Taxi IVE Model Calculation Method}

The IVE model modifies the emission factor of each vehicle's technology type according to its actual situation and combines the total number of vehicles in the study area to obtain the total emission of the entire fleet. Compared with other models, the main feature of the IVE model is that the engine power parameter VSP and the engine working intensity parameter ES are put together to comprehensively consider the relationship between vehicle driving state and emissions.

In the IVE model, emission unit Bin is used to connect the emission rate and driving condition, and the division of Bin is mainly based on specific power (VSP) and engine load (ES).

VSP represents a car made with the power to overcome running resistance in the unit time. Most studies show that VSP can truly reflect the relationship between vehicle driving cycles and the vehicle exhaust pollutant emissions. A VSP equation was calculated by Equation (1) [41]:

$$
\mathrm{VSP}=v\left[1.1 a+9.81 \times(\operatorname{atan}(\sin (\text { grade })))+0.132+0.000302 v^{3}\right]
$$

where 
$v$ is the instantaneous velocity $(\mathrm{m} / \mathrm{s})$;

$a$ is acceleration $\left(\mathrm{m} / \mathrm{s}^{2}\right)$;

grade $=\left(h_{t=0}-h_{t=-1}\right) / v(t=-1$ to 0$)$;

$\mathrm{h}$ is altitude $(\mathrm{m})$.

The IVE model introduces the concept of Engine Stress (ES). This parameter is used empirically to reflect the emission influence from vehicle status due to high engine RPM and the load on the catalyst just prior to the event of interest. That is, the IVE model takes emission history effects into account by using ES.

ES is a dimensionless parameter, which was calculated by Equation (2):

$$
\mathrm{ES}=R P M_{\text {Index }}+0.08 \times P A P
$$

where $R P M_{\text {Index }}$ is engine speed index and PAP is the average of VSP $15 \mathrm{~s}$ before the time of interest,

$$
R P M_{\text {Index }}=v_{t=0} / \text { SpeedDivider }
$$

Values of SpeedDivider for various velocities and powers can be found in the IVE user manual.

For the division of the Bin area, the first step is to classify the research object. VSP is calculated according to the formal data of the vehicle and mapped to the corresponding range in proportion, so 20 Bin areas can be allocated. Meanwhile, 60 Bin areas are formed by dividing the three loads between high and low.

The calculation formula of the IVE model for vehicle emission factor is as follows:

$$
F_{i}=B_{i} \times T_{i} \times V_{i} \times O_{i}
$$

where $F_{i}$ is the actual emission factor; $B_{i}$ is the basic emission factor; $T_{i}$ is the correction factor of technical level; $V_{i}$ is the correction factor of Bin distribution; $O_{i}$ is other correction factors, including environment and fuel, etc.; $i$ is the vehicle type.

\subsection{VMAS Experiments}

According to Qingdao taxi age distribution, a fleet of taxis was chosen. This fleet of taxis was tested on the chassis dynamometer under VMAS. The cycle employed was the Economic Commission for Europe cycle (ECE). Fifteen 1.6L taxis and thirty-five 1.8L taxis were tested. Of these fifty taxis, $89.1 \%$ were fueled with $\mathrm{CNG}$, in which the odometers of $91.4 \%$ were more than $161,000 \mathrm{~km}$. All of the taxis used the original equipment manufacturer (OEM) three-way catalyst (TWC). The regulated emissions for the fifty taxis tested are presented in Table 1. Then, the emission factor of $\mathrm{CO}, \mathrm{HC}$ and NOx were obtained. Emission factors of CO, HC NOx of 1.6L taxis were $0.32 \mathrm{~g} / \mathrm{km}, 0.0384 \mathrm{~g} / \mathrm{km}$, and $0.0216 \mathrm{~g} / \mathrm{km}$, respectively. Emission factors of CO, HC, NOx of $1.8 \mathrm{~L}$ taxis were $5.56 \mathrm{~g} / \mathrm{km}, 1.20 \mathrm{~g} / \mathrm{km}$,

\begin{tabular}{|c|c|c|c|c|c|c|c|c|}
\hline No. & $\begin{array}{l}\text { Model } \\
\text { Year }\end{array}$ & $\begin{array}{l}\text { Engine } \\
\text { Size (L) }\end{array}$ & $\begin{array}{c}\text { Temperature } \\
\left({ }^{\circ} \mathrm{C}\right)\end{array}$ & $\begin{array}{c}\text { Atmospheric } \\
\text { Pressure } \\
\text { (kPa) }\end{array}$ & $\begin{array}{c}\text { Relative } \\
\text { Humidity } \\
\text { (\%) }\end{array}$ & $\begin{array}{c}\mathrm{CO} \\
(\mathrm{g} / \mathrm{km})\end{array}$ & $\begin{array}{c}\mathrm{HC} \\
(\mathrm{g} / \mathrm{km})\end{array}$ & $\begin{array}{c}\mathrm{NO}_{X} \\
(\mathrm{~g} / \mathrm{km})\end{array}$ \\
\hline \#01 & 2008 & 1.6 & 11.7 & 99.5 & 10.1 & 0.3 & 1.60 & 0.90 \\
\hline \#02 & 2008 & 1.6 & 5 & 100.1 & 56.9 & 0.01 & 0.10 & 0.06 \\
\hline \#03 & 2008 & 1.6 & 9.3 & 99.9 & 50.7 & 0.82 & 1.04 & 0.59 \\
\hline \#04 & 2008 & 1.6 & 10.1 & 99.6 & 20.3 & 0.32 & 0.04 & 0.02 \\
\hline \#05 & 2008 & 1.8 & 7.2 & 99.7 & 22.5 & 4.34 & 0.71 & 0.40 \\
\hline \#06 & 2008 & 1.8 & 9.3 & 100.1 & 28.7 & 1.67 & 0.81 & 0.46 \\
\hline \#07 & 2008 & 1.6 & 5.4 & 100.8 & 30.9 & 0.22 & 1.11 & 0.62 \\
\hline \#08 & 2008 & 1.8 & 6.2 & 100.8 & 31.9 & 0.17 & 1.11 & 0.62 \\
\hline
\end{tabular}
$0.68 \mathrm{~g} / \mathrm{km}$, respectively.

Table 1. Regulated emissions for fifty taxis. 
Table 1. Cont.

\begin{tabular}{|c|c|c|c|c|c|c|c|c|}
\hline No. & $\begin{array}{l}\text { Model } \\
\text { Year }\end{array}$ & $\begin{array}{l}\text { Engine } \\
\text { Size (L) }\end{array}$ & $\begin{array}{c}\text { Temperature } \\
\left({ }^{\circ} \mathrm{C}\right)\end{array}$ & $\begin{array}{c}\text { Atmospheric } \\
\text { Pressure } \\
(\mathbf{k P a})\end{array}$ & $\begin{array}{c}\text { Relative } \\
\text { Humidity } \\
(\%)\end{array}$ & $\begin{array}{c}\mathrm{CO} \\
(\mathrm{g} / \mathrm{km})\end{array}$ & $\begin{array}{c}\mathrm{HC} \\
(\mathrm{g} / \mathrm{km})\end{array}$ & $\begin{array}{c}\mathrm{NO}_{X} \\
(\mathrm{~g} / \mathrm{km})\end{array}$ \\
\hline \#09 & 2008 & 1.6 & 7 & 100.8 & 30.5 & 0.77 & 1.32 & 0.75 \\
\hline$\# 10$ & 2008 & 1.8 & 6.8 & 100.9 & 29.7 & 0.77 & 0.70 & 0.39 \\
\hline$\# 11$ & 2008 & 1.8 & 6.5 & 100.9 & 30.4 & 2.49 & 0.58 & 0.33 \\
\hline$\# 12$ & 2009 & 1.8 & 11.7 & 99.4 & 9.3 & 5.09 & 0.86 & 0.48 \\
\hline$\# 13$ & 2009 & 1.8 & 5.2 & 100.5 & 52.5 & 0.16 & 0.01 & 0.01 \\
\hline$\# 14$ & 2009 & 1.8 & 9.1 & 100.1 & 29.7 & 0.59 & 0.69 & 0.39 \\
\hline$\# 15$ & 2009 & 1.8 & 5.9 & 100.8 & 31.7 & 0.26 & 1.05 & 0.59 \\
\hline$\# 16$ & 2009 & 1.6 & 9.4 & 100.1 & 28.9 & 0.11 & 0.56 & 0.31 \\
\hline \#17 & 2009 & 1.8 & 6.6 & 100.8 & 29.2 & 5.56 & 1.20 & 0.68 \\
\hline \#18 & 2009 & 1.8 & 13.4 & 99.1 & 13.2 & 0.35 & 0.03 & 0.01 \\
\hline$\# 19$ & 2009 & 1.8 & 7.1 & 100.8 & 31.7 & 2.67 & 1.46 & 0.82 \\
\hline \#20 & 2009 & 1.8 & 4.6 & 100.1 & 56.5 & 0.25 & 0.08 & 0.05 \\
\hline \#21 & 2009 & 1.8 & 6.3 & 100.8 & 32.1 & 8.21 & 0.83 & 0.47 \\
\hline \#22 & 2009 & 1.8 & 7.7 & 99.9 & 50.2 & 0.46 & 0.04 & 0.03 \\
\hline$\# 23$ & 2009 & 1.8 & 8 & 100.7 & 21.1 & 0.61 & 0.04 & 0.03 \\
\hline \#24 & 2009 & 1.8 & 13.6 & 99.1 & 11.3 & 0.58 & 0.06 & 0.03 \\
\hline$\# 25$ & 2009 & 1.6 & 6.6 & 100.9 & 29.7 & 1.81 & 1.74 & 0.98 \\
\hline \#26 & 2009 & 1.6 & 6.6 & 100.9 & 29.7 & 1.81 & 1.90 & 1.07 \\
\hline \#27 & 2010 & 1.8 & 13.1 & 100 & 34.5 & 2.47 & 0.88 & 0.49 \\
\hline \#28 & 2010 & 1.8 & 7.4 & 100 & 54.3 & 2.83 & 1.04 & 0.58 \\
\hline \#29 & 2010 & 1.8 & 7.4 & 100 & 54.3 & 2.83 & 1.04 & 0.58 \\
\hline \#30 & 2011 & 1.8 & 0.3 & 101.1 & 33.4 & 1.93 & 0.22 & 0.12 \\
\hline \#31 & 2011 & 1.8 & 0.1 & 101.2 & 34.6 & 0.35 & 0.05 & 0.03 \\
\hline \#32 & 2011 & 1.8 & -0.5 & 101.1 & 34.5 & 6.95 & 0.90 & 0.51 \\
\hline \#33 & 2011 & 1.8 & 0.3 & 101.1 & 33.4 & 1.93 & 0.22 & 0.12 \\
\hline \#34 & 2011 & 1.8 & -1.1 & 101.1 & 34.6 & 7.07 & 0.91 & 0.51 \\
\hline \#35 & 2011 & 1.8 & -0.9 & 101.2 & 34.4 & 11.32 & 9.84 & 5.54 \\
\hline \#36 & 2011 & 1.8 & 1.5 & 101.1 & 33.5 & 5.25 & 1.49 & 0.84 \\
\hline \#37 & 2011 & 1.8 & 6.5 & 100.9 & 31.5 & 8.16 & 2.15 & 1.21 \\
\hline \#38 & 2011 & 1.8 & 11.5 & 100.1 & 20.1 & 1.36 & 0.46 & 0.26 \\
\hline \#39 & 2012 & 1.6 & 6.8 & 99.1 & 21.5 & 8.02 & 1.40 & 0.78 \\
\hline$\# 40$ & 2012 & 1.6 & 10.4 & 99.9 & 17.4 & 5.83 & 1.10 & 0.62 \\
\hline \#41 & 2012 & 1.6 & 6.8 & 99.1 & 21.5 & 8.02 & 1.40 & 0.78 \\
\hline$\# 42$ & 2012 & 1.6 & 10.4 & 99.9 & 17.4 & 5.83 & 1.10 & 0.62 \\
\hline$\# 43$ & 2012 & 1.6 & 2.5 & 99.2 & 21.6 & 2.16 & 0.34 & 0.19 \\
\hline$\# 44$ & 2012 & 1.8 & -0.5 & 101.1 & 38.7 & 8.87 & 0.92 & 0.52 \\
\hline$\# 45$ & 2013 & 1.8 & 6.5 & 101.1 & 38.7 & 1.62 & 0.84 & 0.47 \\
\hline$\# 46$ & 2013 & 1.8 & 6.8 & 99.1 & 21.5 & 2.08 & 0.74 & 0.41 \\
\hline \#47 & 2013 & 1.8 & 6.8 & 99.1 & 21.5 & 2.53 & 0.41 & 0.23 \\
\hline \#48 & 2013 & 1.8 & 6.5 & 100.9 & 31.5 & 1.02 & 0.56 & 0.31 \\
\hline \#49 & 2013 & 1.8 & 5.2 & 100.5 & 52.5 & 1.93 & 0.77 & 0.43 \\
\hline$\# 50$ & 2013 & 1.8 & 5.2 & 100.5 & 52.5 & 2.31 & 0.88 & 0.50 \\
\hline
\end{tabular}

\section{Results and Discussion}

\subsection{Driving Condition and VSP Distribution}

After the driving experiments were performed and the data had been analyzed, the driving conditions of the three areas for morning peak hour, evening peak hour and offpeak hour were obtained. Table 2 shows the driving conditions distribution of the business district for morning peak hour, evening peak hour and off-peak hour, respectively. The VSP distribution of the business district is shown in Table 3. 
Table 2. Driving condition distribution of business district for peak hour.

\begin{tabular}{cccc}
\hline $\mathbf{v} / \mathbf{k m} / \mathbf{h}$ & Morning Peak (\%) & Off Peak (\%) & Evening Peak (\%) \\
\hline $0<\mathrm{v} \leq 10$ & 26.4 & 13.1 & 27.6 \\
$10<\mathrm{v} \leq 20$ & 34.8 & 28.2 & 40.1 \\
$20<\mathrm{v} \leq 30$ & 20.4 & 25.5 & 27.3 \\
$30<\mathrm{v} \leq 40$ & 15.1 & 14.1 & 5 \\
$40<\mathrm{v} \leq 50$ & 3.3 & 18.1 & 0 \\
$50<\mathrm{v} \leq 60$ & 0 & 1 & 0 \\
idle ratio & 54.1 & 49.4 & 66.1 \\
acceleration ratio & 19.4 & 22 & 15 \\
constant ratio & 6.7 & 7.1 & 4.2 \\
deceleration ratio & 19.8 & 21.5 & 14.7 \\
\hline
\end{tabular}

Table 3. VSP distribution of business district.

\begin{tabular}{cccc}
\hline & ES Low Load & ES Middle Load & ES High Load \\
\hline VSP range $(\mathrm{kW} / \mathrm{t})$ & {$[-1.6,3.1)$} & {$[3.1,7.8)$} & {$[7.8,12.6)$} \\
{$[-80.0,-44.0)$} & 0.000 & 0.000 & 0.000 \\
{$[-44.0,-39.9)$} & 0.000 & 0.000 & 0.000 \\
{$[-39.9,-35.8)$} & 0.000 & 0.000 & 0.000 \\
{$[-35.8,-31.7)$} & 0.000 & 0.000 & 0.000 \\
{$[-31.7,-27.6)$} & 0.000 & 0.000 & 0.000 \\
{$[-27.6,-23.4)$} & 0.000 & 0.000 & 0.000 \\
{$[-23.4,-19.3)$} & 0.000 & 0.000 & 0.000 \\
{$[-19.3,-15.2)$} & 0.002 & 0.000 & 0.000 \\
{$[-15.2,-11.1)$} & 0.006 & 0.000 & 0.000 \\
{$[-11.1,-7.0)$} & 0.017 & 0.000 & 0.000 \\
{$[-7.0,-2.9)$} & 0.062 & 0.000 & 0.000 \\
{$[-2.9,1.2)$} & 0.618 & 0.000 & 0.000 \\
{$[1.2,5.3)$} & 0.169 & 0.000 & 0.000 \\
{$[5.3,9.4)$} & 0.086 & 0.000 & 0.000 \\
{$[9.4,13.6)$} & 0.027 & 0.000 & 0.000 \\
{$[13.6,17.7)$} & 0.007 & 0.002 & 0.000 \\
{$[17.7,21.8)$} & 0.002 & 0.001 & 0.000 \\
{$[21.8,25.9)$} & 0.001 & 0.000 & 0.000 \\
{$[25.9,30)$} & 0.000 & 0.000 & 0.000 \\
{$[30,1000)$} & 0.000 & 0.000 & 0.000 \\
\hline
\end{tabular}

\subsection{Correction of the Vehicle Emission Factor}

The taxis' operating histories were imported into the VSP calculator, then the VSP distribution of three districts and comprehensive of Qingdao were drawn. Localized parameters were imported into the IVE model and emission factors were calculated. Table 4 shows the average emission factors for Qingdao taxis before correction.

Table 4. Qingdao taxi pollutant emissions factor before correction $(\mathrm{g} / \mathrm{km})$.

\begin{tabular}{cccccc}
\hline & CO & HC & NO $_{\mathbf{X}}$ & SO $_{\mathbf{X}}$ & PM \\
\hline business district & 14.96 & 0.13 & 0.95 & 0.005 & 0.001 \\
higher income area & 14.17 & 0.12 & 0.85 & 0.004 & 0.001 \\
low income area & 10.53 & 0.1 & 0.7 & 0.004 & 0.001 \\
comprehensive & 10.6 & 0.1 & 0.74 & 0.005 & 0.001 \\
\hline
\end{tabular}

The VMAS experimental study only tested the emission factor of $\mathrm{CO}, \mathrm{HC}$ and NOx of the fleet. Therefore, the $\mathrm{CO}, \mathrm{HC}$ and NOx emission factors for the three pollutants were amended. The parameter correction factors are defined as follows:

$$
P C F=\frac{V M A S}{I V E}
$$


PCF represents the parameter correction factor, VMAS represents the measurements of $V M A S$ for the emissions, and IVE represents the IVE analog value of the emissions.

The parameters correction factors of CO, HC and NOx are shown in Table 5:

Table 5. Modification factor of taxi IVE in Qingdao $(\mathrm{g} / \mathrm{km})$.

\begin{tabular}{cccc}
\hline & CO & HC & NO $_{\mathbf{X}}$ \\
\hline measurements of VMAS for the emissions & 2.771 & 0.64 & 0.36 \\
IVE analog value of the emissions & 10.6 & 2.59 & 0.74 \\
parameter correction factor & 0.26 & 0.25 & 0.5 \\
\hline
\end{tabular}

The calculated correction factor of $\mathrm{CO}, \mathrm{HC}$ and NOx are $0.26,0.25$ and 0.5 , respectively. Revised comprehensive emission factors of the business district, higher income areas, lower income area and the whole of the Qingdao City taxi fleet are shown in Table 6.

Table 6. Revised emission factors of Qingdao taxi (g/km).

\begin{tabular}{cccccc}
\hline & CO & HC & NO $_{\mathbf{X}}$ & SO $_{\mathbf{X}}$ & PM \\
\hline business district & 3.45 & 0.13 & 0.48 & 0.005 & 0.001 \\
higher income area & 3.4 & 0.12 & 0.42 & 0.004 & 0.001 \\
low income area & 2.53 & 0.1 & 0.35 & 0.004 & 0.001 \\
comprehensive & 2.55 & 0.1 & 0.37 & 0.004 & 0.001 \\
\hline
\end{tabular}

\subsection{Regulated Emission Characteristics of Taxis with Different Fuels}

According to random questionnaires of 1000 taxis in Qingdao, the total annual mileage of taxis in Qingdao can be calculated. Then, the total annual emissions of taxis in Qingdao, both for regulated and unregulated emissions, can be obtained by the IVE model.

Changing the percentage of the IVE model fleet and refitting gasoline vehicles with different fuels, the emission characteristics of taxis with different fuels were obtained. Total regulated emissions from natural gas taxis and gasoline taxis were contrasted with current taxis in Figure 1.

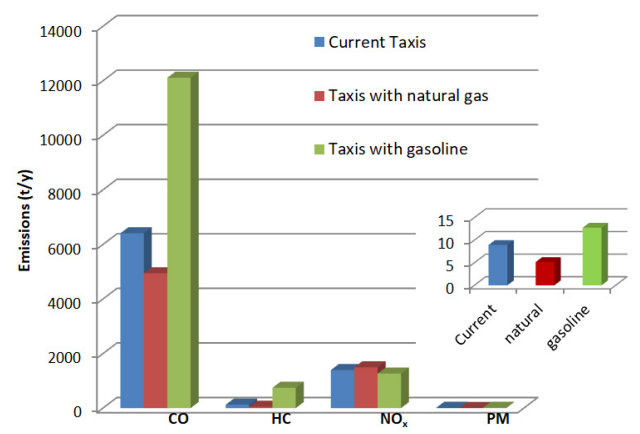

Figure 1. Total regulated emissions from taxis with different fuels.

In Figure 1, according to the same proportion of the new and old taxis, if the taxi fleet was changed into natural gas taxis, $\mathrm{CO}$ and $\mathrm{HC}$ emissions will be reduced by $23 \%$ and $61 \%$, respectively. However, if the taxi fleet was changed to gasoline, $\mathrm{CO}$ and $\mathrm{HC}$ emissions will increase by $89 \%$ and $498 \%$, respectively. The "Oil to Gas" policy will reduce CO and HC emissions greatly.

Compared with current taxis, NOx emissions from taxis with natural gas increased by $7 \%$. However, according to the same proportion of the new and old taxis, if the taxi fleet changed their fuel to gasoline, NOx emissions will be reduced by $9 \%$. As can be seen, the "Oil to Gas" policy does not reduce NOx emissions but slightly increases them. 
PM is a pollutant that has received great attention in recent years. As shown in Figure 1, if the current taxi fleet changes to natural gas, according to the proportion of old and new taxis, PM emissions will be lowered to nearly half the current amount. While taxis are fueled with gasoline, PM emissions will increase by $43 \%$. With the increase in the taxi mileage, PM emissions significantly increase.

\subsection{Unregulated Emission Characteristics of Taxis with Different Fuels}

Total unregulated emissions from natural gas taxis and gasoline taxis are contrasted with current taxis in Figure 2.

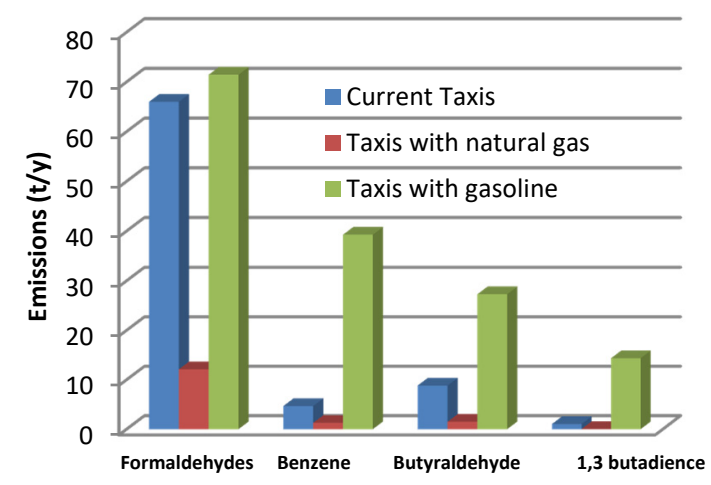

Figure 2. Total unregulated emissions from taxis with different fuels.

In Figure 2, if the current taxis are fueled with natural gas, formaldehydes, benzene, acetaldehyde and 1,3-butadience, emissions will be reduced. Furthermore, formaldehyde emissions will decrease by $82 \%$. However, taxis with gasoline will increase all of the unregulated emissions. Whether fueled with natural gas or gasoline, taxis will produce more unregulated emissions with increased mileage.

\section{Conclusions}

Experiments to obtain the taxi driving conditions and local parameters were investigated, and the IVE localization model was established. Combined with VMAS experiments, the IVE localization model was amended and then taxi pollutant emission factors were drawn. The result indicated that the annual total level of $\mathrm{CO}$ emissions from actual taxis is $6411.87 \mathrm{t}$, HC emissions is $124.85 \mathrm{t}$, NOx emissions is $1397.44 \mathrm{t}$ and PM emissions is $8.9 \mathrm{t}$. When the taxi is running on pure natural gas, the annual emissions of $\mathrm{CO}, \mathrm{HC}$, NOx and PM are $4942.3 \mathrm{t}, 48.15 \mathrm{t}, 1496.01 \mathrm{t}$ and $5.13 \mathrm{t}$, respectively. The annual total formaldehydes, benzene, acetaldehyde, and 1,3-butadience emissions from an actual taxi are $65.99 \mathrm{t}, 4.68 \mathrm{t}, 1.04 \mathrm{t}$ and $8.83 \mathrm{t}$. When the taxi is running on pure natural gas, the annual emissions of formaldehydes, benzene, acetaldehyde, 1,3butadience are $12.11 \mathrm{t}$, $1.27 \mathrm{t}, 1.5 \mathrm{t}$ and $0.02 \mathrm{t}$, respectively. Although a taxi cannot run on pure natural gas to reduce emissions of all types of pollutants, it can still largely reduce pollutant emissions. The "Oil to Gas" policy greatly reduces $\mathrm{CO}, \mathrm{HC}, \mathrm{PM}$, formaldehydes, benzene, acetaldehyde and 1,3-butadience emissions.

According to the experimental analysis in this paper, the implementation of the policy of "replacing oil with gas" will not only improve social benefits in terms of emissions, but it will also reflect economic benefits. The price of natural gas is about half of that of gasoline and diesel with the same equivalent calorific value. Therefore, the "Oil to Gas" policy should be reinforced and increase the frequency of taxis.

Author Contributions: Conceptualization, H.Z.; methodology, L.M.; investigation, Y.L. and J.Q.; data curation, C.S. and X.L.; writing—original draft preparation, H.Z.; writing — review and editing, L.M.; All authors have read and agreed to the published version of the manuscript. 
Funding: This work was supported by the Key Research and Development Plan of Shandong Province of China (NO. 2018GGX105004) and Qingdao Civic Science and Technology Plan (NO.19-61-88-nsh).

Institutional Review Board Statement: Not applicable.

Informed Consent Statement: Informed consent was obtained from all subjects involved in the study.

Data Availability Statement: Not applicable.

Conflicts of Interest: The authors declare no conflict of interest.

\section{References}

1. Beer, T.; Carras, J.; Worth, D.; Coplin, N.; Campbell, P.K.; Jalaludin, B.; Angove, D.; Azzi, M.; Brown, S.; Campbell, I.; et al. The Health Impacts of Ethanol Blend Petrol. Energies 2011, 4, 352-367. [CrossRef]

2. Crosignani, P.; Nanni, A.; Pepe, N.; Pozzi, C.; Silibello, C.; Poggio, A.; Conte, M. The Effect of Non-Compliance of Diesel Vehicle Emissions with Euro Limits on Mortality in the City of Milan. Atmosphere 2021, 12, 342. [CrossRef]

3. Luo, M.; Ji, Y.; Ren, Y.; Gao, F.; Zhang, H.; Zhang, L.; Yu, Y.; Li, H. Characteristics and Health Risk Assessment of PM2.5-Bound PAHs during Heavy Air Pollution Episodes in Winter in Urban Area of Beijing, China. Atmosphere 2021, 12, 323. [CrossRef]

4. Shigeta, N.; Hosseini, S.E. Sustainable Development of the Automobile Industry in the United States, Europe, and Japan with Special Focus on the Vehicles' Power Sources. Energies 2021, 14, 78. [CrossRef]

5. Dias, D.; Antunes, A.P.; Tchepel, O. Modelling of Emissions and Energy Use from Biofuel Fuelled Vehicles at Urban Scale. Sustainability 2019, 11, 2902. [CrossRef]

6. $\quad$ Ouyang, M.G.; Zhang, W.L.; Wang, E.H.; Yang, F.Y.; Li, J.Q.; Li, Z.Y.; Yu, P.; Ye, X. Performance analysis of a novel coaxial power-split hybrid powertrain using a CNG engine and supercapacitors. Appl. Energy 2015, 157, 595-606. [CrossRef]

7. Li, L.G.; Gong, Y.C.; Deng, J.; Gong, X.H. $\mathrm{CO}_{2}$ Reduction Request and Future High-Efficiency Zero-Emission Argon Power Cycle Engine. Automot. Innov. 2018, 1, 43-53. [CrossRef]

8. Huang, Y.H.; Yu, Y.; Yam, Y.S.; Zhou, J.L.; Lei, C.W.; Organ, B.; Zhuang, Y.; Mok, W.C.; Chan, E.F.C. Statistical evaluation of on-road vehicle emissions measurement using a dual remote sensing technique. Environ. Pollut. 2020, 267, 115456. [CrossRef]

9. Shan, X.; Chen, X.; Jia, W.; Ye, J. Evaluating Urban Bus Emission Characteristics Based on Localized MOVES Using Sparse GPS Data in Shanghai, China. Sustainability 2019, 11, 2936. [CrossRef]

10. Liu, H.; Barth, M. Identifying the effect of vehicle operating history on vehicle running emissions. Atomos. Atmos. Environ. 2012, 59, 22-29. [CrossRef]

11. Zhang, W.B.; Qi, Y.; Yan, Y.; Tang, J.J.; Wang, Y.H. A method of emission and traveller behavior analysis under multimodal traffic condition. Transp. Res. Part. D 2017, 52, 139-155. [CrossRef]

12. Guo, D.; Wang, Z.G.; Sun, L.; Li, K.; Wang, J.; Sun, F.; Zhang, H. Study on Gasoline Vehicle Emission Inventory Considering Regional Differences in China. J. Adv. Transp. 2018, 2018, 7497354. [CrossRef]

13. Yang, W.; Yu, C.Y.; Yuan, W. High-resolution vehicle emission inventory and emission control policy scenario analysis, a case in the Beijing-Tianjin-Hebei (BTH) region. China. J. Clean. Prod. 2018, 203, 530-539. [CrossRef]

14. Bruce, O.; Huang, Y.H.; Zhou, J.L.; Surawski, N.C.; Yam, Y.S.; Mok, W.C.; Hong, G. A remote sensing emissions monitoring programme reduces emissions of gasoline and LPG vehicles. Environ. Res. 2019, 177, 108614.

15. Huang, Y.H.; Surawski, N.; Yam, Y.S. Re-evaluating effectiveness of vehicle emission control programmes targeting high-emitters. Nat. Sustain. 2020, 3, 904-907. [CrossRef]

16. Al-Arkawazi, S.A.F. The gasoline fuel quality impact on fuel consumption, air-fuel ratio (AFR), lambda (lambda) and exhaust emissions of gasoline-fueled vehicles. Cogent Eng. 2019, 6, 1616866. [CrossRef]

17. Al-Rawi, Y.A.; Imlus, M.H.; Yusup, Y.; Yahya, S.B. Factors affecting vehicle exhaust emissions, driver motivations as a mediator. Environ. Econ. Policy Stud. 2020, 23, 361-407. [CrossRef]

18. Giechaskiel, B.; Casadei, S.; Mazzini, M.; Sammarco, M.; Montabone, G.; Tonelli, R.; Deana, M.; Costi, G.; Tanno, F.D.; Prati, M.V. Inter-Laboratory Correlation Exercise with Portable Emissions Measurement Systems (PEMS) on Chassis Dynamometers. Appl. Sci. 2018, 8, 2275. [CrossRef]

19. Huang, Y.; Mok, W.C.; Yam, Y.S.; Zhou, J.L.; Surawski, N.C.; Organ, B.; Chan, E.F.C.; Mofijur, M.; Mahlia, T.M.I.; Ong, H.C. Evaluating in-use vehicle emissions using air quality monitoring stations and on-road remote sensing systems. Sci. Total Environ. 2020, 740, 139868. [CrossRef]

20. Yao, Z.L.; Cao, X.Y.; Shen, X.B.; Zhang, Y.Z.; Wang, X.T.; He, K.B. On-road emission characteristics of CNG-fueled bi-fuel taxis. Atmos. Environ. 2014, 94, 198-204. [CrossRef]

21. Yue, T.T.; Chai, F.H.; Hu, J.N.; Jia, M.; Bao, X.F.; Li, Z.H.; He, L.Q.; Zu, L. Gaseous emissions from compressed natural gas buses in urban road and highway tests in China. J. Environ. Sci. 2016, 48, 193-199. [CrossRef] [PubMed]

22. Huang, X.Y.; Wang, Y.; Xing, Z.Y.; Du, K. Emission factors of air pollutants from CNG-gasoline bi-fuel vehicles: Part II. CO, HC and NOx. Sci. Total Environ. 2016, 565, 698-705. [CrossRef] [PubMed]

23. Wang, Y.; Xing, Z.Y.; Xu, H.; Du, K. Emission factors of air pollutants from CNG-gasoline bi-fuel vehicles: Part I. Black carbon. Sci. Total Environ. 2016, 572, 1161-1165. [CrossRef] 
24. Liu, J.; Dong, J.J.; Shi, X.P.; Wang, H.Z.; Yang, H.M. Research for NOx Emission of Nanjing Vehicle Based on IVE Model. Arch. Build. Mater. 2011, 99-100, 1341.

25. Bruce, O.; Huang, Y.H.; Zhou, J.L.; Yam, Y.S.; Mok, W.C.; Chan, E.F.C. Simulation of engine faults and their impact on emissions and vehicle performance for a liquefied petroleum gas taxi. Sci. Total. Environ. 2020, 716, 137066.

26. Apt, J.; Peterson, S.B.; Whitacre, J.F. Battery Vehicles Reduce $\mathrm{CO}_{2}$ Emissions. Science 2011, 33, 823. [CrossRef]

27. Choi, K.; Zhang, M. The net effects of the built environment on household vehicle emissions: A case study of Austin, TX. Transp. Res. Part. D-Transp. Environ. 2017, 50, 254-268. [CrossRef]

28. Nesamani, K.S. Estimation of automobile emissions and control strategies in India. Sci. Total Environ. 2010, 408, 1800-1811. [CrossRef] [PubMed]

29. Cao, X.Y.; Yao, Z.L.; Shen, X.B.; Ye, Y.; Jiang, X. On-road emission characteristics of VOCs from light-duty gasoline vehicles in Beijing, China. Atmos. Environ. 2016, 124, 146-155. [CrossRef]

30. Idris, N.; Sukri, S.; Saadon, I.M. Development of volatile organic compounds (VOC) removal filter for transport air-conditioner and VOC removal test. Proc. Mech. Eng. Res. Day 2018, 2018, 38-39.

31. Buss, W.; Masek, O. High-VOC biochar-effectiveness of post-treatment measures and potential health risks related to handling and storage. Environ. Sci. Pollut. Res. 2016, 23, 19580-19589. [CrossRef]

32. Fontaras, G.; Martini, G.; Manfred, U.; Marotta, A.; Krasenbrink, A.; Maffioletti, F.; Terenghi, R.; Colombo, M. Assessment of on-road emissions of four Euro V diesel and CNG waste collection trucks for supporting air-quality improvement initiatives in the city of Milan. Sci. Total Environ. 2012, 426, 65-72. [CrossRef] [PubMed]

33. Wang, H.Y.; Huang, C.; Hu, Q.Y. Correlations of Light-duty Gasoline Vehicle Emissions Based on VMAS and CVS Measurement Systems. Huanjing Kexue 2017, 38, 2294-2300.

34. Zhang, X.; Liu, F.J.; Cai, F.T.; Dong, G.L.; Liu, J.X. Research on Influencing Factors on Errors of Vehicle Fuel Consumption Measured by Carbon Balance Method Based on Vmas. Gonglu Jiaotong Keji. 2010, 27, 138-142. [CrossRef]

35. Liu, P.; Li, R.X. Speed Signal Processing of VMAS (Vehicle Mass Analysis System) Based on Adaptive Kalman Filter. Mech. Sci. Technol. 2011, 30, 1850-1854.

36. Wang, M.L.; Jin, B.Q.; Li, S.Y. Study on Emission Limits under VMAS for In-use Vehicles in Zhengzhou. Environ. Sci. Technol. 2019, 42, 214-220.

37. Zamboni, G.; André, M.; Roveda, A.; Capobianco, M. Experimental evaluation of Heavy Duty Vehicle speed patterns in urban and port areas and estimation of their fuel consumption and exhaust emissions. Transp. Res. Part. D 2015, 35, 1-10. [CrossRef]

38. Zhao, Q.; Chen, Q.; Song, G.H. Comparative Study of VSP Binning Methods for Estimating Fuel consumptions of LDVs on Urban Roads. ESAT 2018 2019, 2066, 20059.

39. Zhang, H.L.; Wu, W.; Wang, C. Model Established on Exhaust Emissions of Vehicle Based on Speed and Vehicle Specific Power. ECAR 2018 2018, 307, 756-767.

40. Song, G.H.; Yu, L.; Wu, Y.Z. Development of Speed Correction Factors Based on Speed-Specific Distributions of Vehicle Specific Power for Urban Restricted-Access Roadways. Transp. Eng. J. ASCE 2016, 142, 04016. [CrossRef]

41. Lents, J.; Davis, N. IVE Model Users Manual; ISSRC-2004. Available online: http://www.issrc.org/ive/downloads/manuals/ UsersManual.pdf (accessed on 8 April 2021). 